\title{
ע Sisäilma ja identiteetit: Identiteettityö työpaikan sisäilmaongelmien kontekstissa
}

Sisäilmaongelmien yhteys erilaisiin terveysongelmiin on edelleen osittain kiistanalainen. Tämä voi vaatia sisäilmasta oireilevilta tai sairastuneilta tavallista intensiivisempää identiteettityötä. Analysoimme tässä tutkimuksessa diskurssianalyyttisestä näkökulmasta, millaisia erilaisia identiteettejä vastaajat tuottivat, kun he kirjoittivat kokemuksistaan työpaikkansa sisäilmaongelmista. Esseeaineisto oli kerätty Suomalaisen Kirjallisuuden Seuran kautta $(N=20$ vastaajaa). Tunnistimme kuusi erilaista identiteettiä, joissa kussakin kirjoittaja haki eri tavoin moraalista tunnustusta itselleen: normaali yksilö, hyvä ihminen, rationaalinen toimija, oikeutettu uhri, kärsimyksen viisastama ja yhteisten oikeuksien ajaja. Identiteetit erottuivat toisistaan sen mukaan, kuinka eroa sairastuneen ja terveiden välille rakennettiin, korostiko kirjoittaja niissä yksilöllisiä ominaisuuksia vai ryhmäjäsenyyksiä, kuinka heikkoja tai vahvoja toimijuuksia identiteetit tarjosivat ja mitä erilaisia stigmoja niillä pyrittiin torjumaan. Sama vastaaja saattoi tuottaa useaa erilaista identiteettiä, ja identiteettityötä leimasi tasapainottelu niiden eri muotojen välillä. Sisäilmaongelmista kärsivien potilaiden kunnioittava kohtaaminen edellyttää terveydenhoitohenkilökunnalta ymmärrystä potilaiden haastavasta identiteettityöstä ja niistä stigmoista, joita identiteettityöllä pyritään torjumaan.

\section{ASIASANAT: sisäilmaongelmat, identiteetti, kiistanalaiset sairaudet, diskurssianalyysi}

\section{EERIKA FINELL, EERO SUONINEN, TUIJA SEPPÄLÄ}

\section{YDINASIAT}

- Tutkimusta sisäilmasta oireilevien identiteettityöstä on olemassa hyvin vähän.

- Tunnistimme kuusi identiteettityyppiä, joita vastaajat rakensivat samalla, kun he kuvasivat työpaikkansa sisäilmaongelmia.

- Identiteettityypeillä vastaajat hakivat eri tavoin moraalista tunnustusta.

- Terveydenhoitohenkilökunnan tulisi tunnistaa sisäilmasta kärsivien potilaiden haastava identiteettityö ja ne stigmat, joita identiteettityöllä pyritään torjumaan.

\section{JOHDANTO}

Kokemus siitä, että oireilee työpaikan sisäilmasta, voi olla raskas. Vaikka tutkimusnäyttöä hengityselimiin liittyvien oireiden ja astman kohdalla on paljon (1-3), erityisesti epäspesifimpien oireiden kohdalla näyttö on ristiriitaista (4). Sisäilman laadun vaikutuksista terveyteen käydäänkin Suomessa tiivistä yhteiskunnallista keskustelua. Aikaisempi tutkimus on osoittanut, että kiistanalainen oireilu ja sairastaminen lisäävät epävarmuuden kokemuksia ja sosiaalisen tuen tarvetta (5). Tällaisessa tilanteessa sosiaalisen tuen saaminen saattaa kuitenkin olla tavallista vaikeampaa ja sairastuneet raportoivatkin usein kokemuksia siitä, ettei heitä ole uskottu, he ovat kokeneet syrjintää 
tai heidän mielenterveyttänsä on kyseenalaistettu (6-8). Sairauskokemuksen kyseenalaistuminen puolestaan uhkaa yksilön moraalista arvokkuutta ja sitä kautta johdattaa sairastuneen kiinnittämään erityistä huomioita siihen, millaisena moraalisena toimijana sairastunut näkee itsensä ja miten hän tätä moraalisuuttaan muille esittää (5,9-10). Tämän takia kokemus työpaikan sisäilmasta sairastumisesta saattaa siis johtaa tavallista intensiivisempään identiteettityöhön. Käsitteellä moraalinen arvokkuus viittaamme goffmanilaiseen kasvojen säilyttämiseen, jossa ihminen pyrkii suojamaan yksilön arvon muiden silmissä ja säilyttämään yhteisön hyväksynnän (11).

Tässä artikkelissa tavoitteenamme on lisätä ymmärrystä niistä erilaisista tavoista, joilla työpaikan sisäilmaongelmista kärsivä voi rakentaa identiteettiään. Identiteetin käsitteellä voidaan tarkoittaa erityyppisiä asioita ja se voidaan ymmärtää hyvin monin eri tavoin teoriaperinteestä riippuen. Usein käsite määritellään verrattain staattiseksi yksilön ominaisuudeksi, joka liittyy kiinteästi joko aikaisemman elämän kokemuksiin $(12,13)$ tai ryhmänjäsenyyksiin $(14,15)$. Tässä artikkelissa identiteetin käsitettä tarkastellaan sosiaalisen konstruktionismin viitekehyksessä kielellisesti rakentuvana ilmiönä. Tällöin identiteetillä tarkoitetaan sitä, millaiseksi yksilö on kuvattavissa uskottavalla tavalla. Tämä uskottavuus pitää sisällään aina myös moraalisen ulottuvuuden, käsityksen siitä, millainen ihminen mielletään kussakin hetkessä ja paikassa "ideaalina”. Näin ymmärrettynä identiteetti ei ole yksi koherentti yksilön ominaisuus, vaan hänen on mahdollista rakentaa kielen avulla itselleen useita rinnakkaisia identiteettejä ja neuvotella niistä toisten kanssa. Nämä kielellisesti muotoillut identiteetit voivat poiketa suurestikin toisistaan ankkuroituessaan eri tavoin sosiaalisiin suhteisiin ja vallitseviin puhetapoihin. (16.)

Käyttämämme identiteetin käsitteen määrittely liittyy diskurssianalyyttiseen lähestymistapaan. Tässä lähestymistavassa tutkitaan kielellisiä käytäntöjä siitä näkökulmasta, miten ne rakentavat sosiaalista todellisuutta. Kielelliset kuvaukset eivät kuitenkaan voi olla mitä tahansa, vaan niiden on liityttävä myös oman aikakautensa puhetapoihin eli diskursseihin. Lähestymistapa soveltuu hyvin sellaisten kiistanalaisten aiheiden kuten sisäilmaongelmien tarkasteluun, jossa kielenkäyttäjältä edellytetään tasapainoilua eri- laisten, aikakautenaan ymmärrettävien näkökohtien välillä. (17.)

Tässä artikkelissa tunnistamme sellaisten kielellisten puhetapojen vaihtelua, joilla työpaikan sisäilmaongelmista kärsineet kuvaavat omaa tilannettaan sisäilmaongelmien kontekstissa. Emme kuitenkaan tarkastele näitä kuvauksia todellisuuden realistisina kuvina, vaan kielellisinä oman toiminnan ja tilanteen ymmärrettäväksi tekemisen keinoina, joilla kirjoittajat rakentavat itselleen identiteettejä suhteessa aikakauden yleisiin keskustelu-ulottuvuuksiin. Tällainen identiteettityön tutkimus on merkityksellistä ainakin kolmesta eri syystä. Ensinnäkin, sen avulla on mahdollista hahmottaa, kuinka kokonaisvaltaisesti kokemus sisäilmasta sairastumisesta voi koskettaa yksilöiden sosiaalista minuutta. Toiseksi, se auttaa ymmärtämään sitä, minkälaisten syvälle menevien moraalisten dilemmojen kanssa nämä henkilöt joutuvat painimaan käsitellessään muiden ihmisten kanssa kokemaansa. Kolmanneksi, sen kautta on mahdollista tuottaa uutta tietoa niiden toimijoiden käyttöön, jotka ovat ratkomassa työpaikkojen sisäilmaongelmia käytännössä. Mikäli työpaikan haitalliseksi koettuun sisäilmastoon yhdistyy sosiaalisen tuen puutetta tai epäoikeudenmukaisuuden kokemuksia, tämä lisää työntekijöiden pitkiä sairauspoissaoloja suhteessa tilanteeseen, jossa työntekijä raportoi sisäilmaston haittaa mutta ei sosiaalista stressiä (18). Siksi käytännön toimenpiteiden lisäksi tieto siitä, miten voidaan edistää nähdyksi ja kohdatuksi tulemista on keskeistä asiakas-, esimies-, ja potilastyössä sisäilmaongelmien kontekstissa.

\section{AINEISTO JA MENETELMÄ}

Tutkimusaineistona toimivat esseekirjoitukset, joissa kirjoittajat kuvailevat omia sisäilmaongelmiin liittyviä kokemuksia tuntemattomalle yleisölle. Tämä aineisto kerättiin Suomalaisen Kirjallisuuden Seuran (SKS) ja ensimmäisen kirjoittajan järjestämässä kirjoituskeräyksessä vuoden 2014 aikana. Yhteensä $56^{1}$ vastaajaa lähetti kirjoituksen. Tämän artikkelin aineistoksi valittiin niiden 20 vastaajan kirjoitukset, jotka käsittelivät erityisesti työpaikan sisäilmaongelmia. Vastaajista 18 oli naisia ja 2 miehiä. Vain 11 raportoi ikänsä (Ka =53). Kaikki vastaajat olivat jossain vaiheessa kärsineet oireista, jotka he liittivät työpaikkansa haitalliseksi koettuun sisäilmaan. Vastaajista 10 oli kirjoitushetkellä työelämässä. Kirjoitusten pi- 
tuudet vaihtelivat 179 sanasta 9440 sanaan. Lausunto tutkimuksen ihmistieteiden eettisestä ennakkoarvioinnista on tehty Tampereen yliopistossa. Analyysiprosessi eteni siten, että ensimmäinen kirjoittaja teki alustavan analyysin, jonka kolmas kirjoittaja kävi läpi esittäen täydentäviä kommentteja. Lopuksi toinen kirjoittaja vielä arvioi analyysin. Prosessi eteni keskustellen eikä tutkijoiden keskinäisiä erimielisyyksiä esiintynyt.

Aineiston analyysissä sovelsimme diskurssianalyyttistä lähestymistapaa aineistolähtöisesti Diskurssianalyysissä on tyypillistä tarkastella kielenkäytön vaihtelun säännönmukaisuuksia. (17). Aloitimme analyysin tutustumalla huolellisesti aineistoon ja tämän jälkeen tunnistimme laajasta tekstimassasta ne kohdat, joita voidaan pitää identiteettipuheena. Tarkensimme identiteettipuheen tulkintaa myös kategoria-analyyttisiä työkaluja soveltamalla. Kategoria-analyysillä tarkoitetaan tutkimussuuntausta, jossa kategorisointien katsotaan olevan vaikeasti havaittavalla, mutta säännönmukaisella tavalla keskeisiä arjen käytännöissä. Tässä artikkelissa tehtävän analyysin kannalta on olennaista, että kategorioiden katsotaan olevan "päätelmärikkaita" siten, että kategorioiden ja määreiden oletetaan liittyvän säännönmukaisilla tavoilla yhteen. Näin ollen määreiden mainitseminen voi vihjata kategorioihin, vaikkei niitä mainittaisikaan (19.) Kategoria-analyysin avulla on siis mahdollista tunnistaa tarkasti kategorioita, tässä tapauksessa identiteettikategorioita. Hyödynsimme tätä ideaa, kos$\mathrm{ka}$ aineistossamme identiteettejä ei ilmaistu aina suoraan mainiten (esim. "Olen rationaalinen toimija") vaan usein mainitsemalla niihin assosioituvia ominaisuuksia (esim. "Heitin ohjeiden mukaan pois kaikki työtilassani olleet tavarat: irtaimen paperin, lehtiöt, vihot ...”).

Toinen analyysimme erityispiirre on, ettei siinä kiinnitetty huomiota pelkästään merkityksenantoihin, vaan myös niiden retorisiin muotoiluihin, joilla kirjoittaja pyrkivät lisäämään kielenkäytön vakuuttavuutta. Tässä tarkoituksessa nojauduimme niin sanotun uuden retoriikan traditioon, jolla tarkoitetaan niiden keinojen tarkastelua, joilla erilaisista väitteistä tehdään uskottavia ja joilla luodaan sitoutumista niihin. Sovelsimme erityisesti uuden retoriikan piirissä kehitettyjä tapoja eritellä ja nimetä retoristen keinojen tai strategioiden kirjoa ja käyttötapoja. Yleisesti käytettyjä retorisia keinoja ovat esi- merkiksi 'etäännyttäminen omista intresseistä', 'puhujakategorialla oikeuttaminen', 'yksityiskohdilla ja kertomuksilla vakuuttaminen', 'määrällistäminen', 'ääri-ilmaukset' ja 'vasta-argumenttiin valmistautuminen'. $(17,20$.)

\section{IDENTITEETTIEN KIRJ0}

Aloitamme analyysin tulosten esittelyn havainnollistamalla, kuinka sama henkilö saattaa rakentaa useita erilaisia identiteettejä ja kuinka nämä identiteetit muodostavat toisinaan jopa tiheästi kumuloituvan sarjan. Tästä esimerkkinä toimii ensimmäinen aineisto-ote, johon olemme poimineet katkelmia yhdestä saman kirjoittajan tekstistä. Tarkoituksenamme ei ole kiinnittää huomiota pelkästään sellaisiin identiteetteihin, joita kirjoittaja liittää suoraan sisäilmaongelmaan, vaan tunnistaa kaikkia niitä identiteettejä, joita kirjoittaja rakentaa itselleen omakohtaisesti koetun sisäilmaongelman kuvaamisen kontekstissa. Kuvausten jälkeen olemme merkinneet kursiivilla tulkintamme siitä, millaisesta identiteetistä edeltävässä tekstissä on kyse. Tarkoituksemme on antaa suuntaa antava käsitys siitä identiteettien valikoimasta, joita tässä artikkelissa käsitellään.

Ote 1: "Sisäilmaongelma on nimenomaan ilman ongelma, ei minun. Vika ei ole minussa, vaikka osa työkavereista ja ympäristöstä niin ehkä ajattelee. [normaali yksilö] Koska olin oman yksikköni ensimmäinen sairastunut, niin ajatteli ensin myös työterveyslääkäri ja sairaus ehti puhjeta astmaksi ennen kuin sain väistömääräyksen ja nyt olen astmaatikko lopun elämääni. [oikeutettu ubri]

Toisaalta, työkavereita on kiittäminen siitä, että alun perin menin lääkäriin. Oireet alkoivat, kun vaihdoin työhuonetta. Olin iloinen, kun sain ensimmäistä kertaa työurallani oman huoneen. [byvä ibminen].[...]

Yskä rajoittui työpaikalle, enkä ollut ollut flunssassa tai muuta, joten en ajatellut olevani sairas. [...] Sen lukuvuoden aikana kävin lääkärissä kymmeniä kertoja, otin kokeeksi hoitavan astmalääkekuurin, jonka aikana yskä vähän rauhoittui, ja olin töissä avaavan lääkkeen avulla. Välillä jouduin lähtemään kokouksista pois ja työntämään pään ulos ikkunasta, että sain happea. [...] Oireet helpot- 
tivat taas kesälomalla. Seuraavana syksynä ne palasivat viikossa ja menin oitis lääkäriin, tällä kertaa visusti varmana siitä, että kaikki johtuu työpaikasta. [rationaalinen toimija] [...] Vaikka kuulostaa hullulta, olen iloinen, että jos joku oire oli pakko olla, se oli juuri astma kuuluvine yskineen, koska sitä ei voi kukaan kiistää. Astma on myös selkeä sairaus, jonka kaikki tajuavat [oikeutettu ubri].[ ...] Välillä kyllä minua on kiehuttanut istua muuttoa koskevissa kokouksissa kuuntelemassa väninää muutaman homeisen kirjan takia. Itsekin arvostan kirjoja, ja niistä harmittaa luopua, mutta hengittäminen on vielä arvokkaampaa. [kärsimyksen viisastama] [...] Vaikka kenellekään ei saisi toivoa pahaa [hyvä ihminen], silti ajattelen, että toivottavasti ne, jotka vähättelevät sisäilmaoireita, tai tieten tahtoen rakentavat tai remontoivat sutta ja sekundaa, saavat keuhkoahtaumataudin ja kuolevat tuskallisen tukehtumiskuoleman. Sisäilmaoireissa ei ole mitään vähäteltävää, ne ovat todellisia ja ne rajoittavat ihmisten elämää rajustikin. [ybteisten oikeuksien ajaja].” (Marja)

Tässä yhden vastaajan kirjoituksessa esiintyvät, joskin omien persoonallisten painotusten ja muotoilujen kautta, kaikki ne kuusi identiteetin muotoa, jotka tunnistimme olennaisiksi koko aineiston kannalta. Identiteetit, joita käsitellään seuraavassa yksityiskohtaisesti, ovat käsittelyjärjestyksessä normaali yksilö, hyvä ihminen, rationaalinen toimija, oikeutettu uhri, kärsimyksen viisastama ja yhteisten oikeuksien ajaja. Keskimäärin yksittäisistä kirjoituksista on tunnistettavissa 4-5 tapaa rakentaa identiteettiä.

\section{NORMAALI YKSILÖ}

Rakentaessaan normaalin yksilön identiteettiä, kirjoittajat häivyttävät tavallisen terveen yksilön ja sisäilmasta sairastuneen eroa. Tämä toteutui jo otteen 1 alkuriveillä muotoilussa "Sisäilmaongelma on nimenomaan ilman ongelma, ei minun. Vika ei ole minussa, vaikka osa työkavereista ja ympäristöstä niin ehkä ajattelee." Seuraavassa otteessa normaalin yksilön identiteetti rakennetaan korostamalla samantyyppisesti, että oireet ovat asiaankuuluvia kehon rektioita sairaaseen ympäristöön.
Ote 2: "Kohtasin 90-luvun alkupuolella yllättävän ongelman. Sain jatkuvia yskäisiä, rajuja flunssia vieraakseni. Harmistuin [sen] vuoksi, koska en päässyt työhön. En osannut ajatella, että työtila oli se, joka oli todella sairas. Minä vain oireilin tilan vuoksi. [...] Sain siirron toiseen työpisteeseen. Pienessä mielessäni ei käväissyt, että oireet olisivat johtuneet sairaasta työtilasta. Tilanteeni näytti korjautuvan työtilavaihdon myötä. Näin jälkikäteen muistan, kuinka väsynyt olin sairaassa työtilassa.” (Hertta)

Otteen 2 alussa kirjoittaja, joka on joutunut jäämään eläkkeelle työperäisen astman takia, ottaa etäisyyttä sairaan kategoriaan kirjoittamalla, että sai vieraakseen infektioita. Näin hän korostaa sairautta väliaikaisena ongelmana. Tämän jälkeen kirjoittaja jatkaa ilmauksella "[...] työtila oli se, joka on todella sairas. Minä vain oireilin tilan vuoksi." Kategoria-analyysiä soveltaen voidaan päätellä, että näin kirjoittaja tulee kirjoittaneeksi 'oireilusta' tavalla, joka on mahdollista kuulla kategorian 'sairas' kategoriasidonnaisena määreenä. Samalla hän kuitenkin korostaa voimakkaasti kategoriaa 'sairas työtila' ja painottaa tätä kuvausta sanalla 'todella'. Näillä kaikilla keinoilla hän etäännyttää itseään tehokkaasti sairaan ihmisen kategoriasta.

Myös otteen loppupuolen ilmaus "Pienessä mielessäni ei käväissyt, että oireet olisivat johtuneet sairaasta työtilasta” on kiinnostava. Kirjoittaja luo näin tehokkaasti vaikutelmaa, että hän on tehnyt päätelmänsä vasta realististen havaintojen jälkeen. Kertomuksellinen ajan jaksottaminen toimii retorisena keinona sen epäilyksen torjumiseen, että kyseessä olisi asenteellinen tai harhainen ihminen. Kirjoittajan kuvatessa, ettei hän voinut aluksi kuvitella työtilan olevan sairas, hän vierailee samalla rationaalisen toimijan identiteetissä tavalla, joka hälventää riskiä tulla tulkituksi luulosairaana. Vaikka identiteetit ovatkin siis erillisiä, ne voivat tukea toisiaan esimerkiksi siten, että normaalin yksilön identiteetti vahvenee, kun sen yhteyteen liitetään myös rationaalisen identiteetin rakentamista.

Myös seuraavan otteen kirjoittaja etäännyttää itseään tavallisesta sairaan kategoriasta. 
Ote 3: "Uudet home-tuttavani aspergillus, penicillinium, chaetomium, geotrichum, paecilomyces sekä aktinobakteerit kävivät keskenään kemiallista sodankäyntiä ja minä satuin vain oleskelemaan siinä samassa tilassa sivullisena." (Olli)

Otteessa kirjoittaja luettelee erilaisia mikrobeja käyttämällä niiden tieteellisiä nimiä. Nämä keskenään kemiallista sotaa käyvät mikrobit esitetään toimijoina, joiden välisessä konfliktissa kertoja itse sattuu vain olemaan sivullisena paikalla. Kirjoittaja kuvaa siten kärsimyksensä täysin irralliseksi omista ominaisuuksistaan ja teoistaan. Kärsimykset johtuvat ulkoisista satunnaisista toimijoista. Aiemmin nähdyn otteen 1 kirjoittaja sijoittaa kärsimyksensä syyn itsensä ulkopuolelle vielä suoremmin muotoilullaan "Sisäilmaongelma on nimenomaan ilman ongelma, ei minun. Vika ei ole minussa [...]". Normaalin yksilön identiteetin rakentamisessa siis luodaan vaikutelmaa siitä, ettei kertojan mielessä tai ruumiissa ole vikaa ja että vastuu sairastumisesta sijoittuu oman keho- mielen ulkopuolelle.

\section{HYVÄ IHMINEN}

Hyvän ihmisen identiteettiä rakennetaan korostamalla positiivisia kategorioita, jotka liittyvät toisten ihmisten inhimilliseen ymmärtämiseen, kansalaisena toimimiseen tai tunnollisen työntekijän asemaan. Identiteettiä voidaan rakentaa pienillä maininnoilla, kuten "Toisaalta, työkavereita on kiittäminen siitä, että alun perin menin lääkäriin" tai "Toisaalta, ymmärrän senkin, että ei lääkäri ala yhden ibmisen oireiden takia väistörulijanssia" tai "Koulupäivästä selvisi, kun söi ketjussa Sisu-pastilleja [...] Sairauspoissaoloja en uhallakaan hankkinut [...]".

Seuraavissa otteissa (4 ja 5) hyvän ihmisen identiteetti rakentuu monisanaisemmin.

Ote 4: "Nyt toimin päiväkodissa Mannerheimin lastensuojeluliiton kylämummina 2 kertaa kuussa kahdessa ryhmässä. Hoidan terveyttäni käymällä 2 kertaa viikossa kuntosalilla ja sen jälkeen tunnin jumpalla. Olen mukana eläkeläisryhmässä, käyn tapaamisissa ja rivitanssiharjoituksissa. Olemme esiintyneet vanhainkodeissa ja muissakin tapahtumissa." (Helena)
Tässä otteessa kirjoittaja, joka on raportoinut kärsivänsä työperäisestä astmasta ja kroonisesta kurkkutulehduksesta, rakentaa itselleen vahvasti hyvän ihmisen identiteettiä. Hän kertoo tekevänsä vapaaehtoistyötä sekä hoitavansa terveyttään hyvin aktiivisesti. Lisäksi hän kertoo ulospäin suuntautuneista ja aktiivisista harrastuksistaan. Kirjoittajan ei ole tarpeen nimetä itseään hyväksi ihmiseksi tai kansalaiseksi. Itse asiassa tällainen nimeäminen kuultaisiin herkästi itsekehuna. Identiteetin rakentaminen tapahtuukin siten, että hän mainitsee joukon edellä kuvattuja kategoriasidonnaisia ominaisuuksia, jotka assosioituvat voimakkaasti hyvän ihmisen kategoriaan. Kiinnostavaa on myös se, että kirjoittaja antaa yksityiskohtaista tietoa aktiivisuutensa lukumääristä (esim. "kylämummina 2 kertaa kuussa kahdessa ryhmässä"). Tällainen määrällistäminen on retorinen keino, jota käytetään usein tuottamaan luotettavuuden vaikutelmaa.

Seuraavassa otteessa hyvän ihmisen identiteetin rakentaminen tapahtuu hieman erityyppisen kuvauksen kautta.

Ote 5: "Olen iloinen, tarmokas, innostuva, lapsirakas, työstäni innostunut ja kiinnostunut lastenohjaaja. Työ oli monipuolista ja kiinnostavaa, sekä lapset ihanan energisiä, ilosilmäisiä; kiinnostuksen kukkamaan touhuilijoita." (Hertta)

Tässä otteessa kirjoittaja rakentaa identiteettiään kahdella eri tavalla. Ensinnäkin hän ottaa etäisyyttä sairaan kategoriaan kuvaamalla kuuluvansa korkeamman statuksen kategoriaan lastenohjaaja. Retorisen perinteen sanastolla ilmaistuna kyse on kategorian käytöstä vakuuttamisen välineenä. Hän kiinnittyy vahvasti ammatilliseen kategoriaan siitä huolimatta, että kertoo myöhemmin esseessään saaneensa tapaturmaeläkkeen työpaikan sisäilmaongelmista johtuen. Toiseksi hän kuvaa itsensä positiivisena luonteena sellaisin määrein, kuten iloinen ja innostuva, sekä hyvänä työntekijänä sellaisin määrein, kuten tarmokas ja lapsirakas. Lapsirakkaan vaikutelma vahvenee edelleen, kun lapset kuvataan runollisesti energisiksi ilosilmiksi ja "kiinnostuksen kukkamaan" touhuilijoiksi. Koska otteen kontekstina on kirjoittajan ammatti, nämä määreet toimivat paitsi kirjoittajan persoonallisuuden kuvauksina, myös 
tätä laajemmin hyvän työntekijän, jopa hyvän kansalaisen, kategoriasidonnaisina ominaisuuksina.

\section{RATIONAALINEN TOIMIJA}

Mielekästä identiteettiä on mahdollista rakentaa myös korostamalla omaa rationaalista toimintaa sisäilmaongelmien kohdatessa. Usein tätä toimintaa käsitellään omien vaikeiden oireiden ja mittavien vastoinkäymisten kehyksessä. Kuvattavat vastoinkäymiset voivat liittyä hyvin monitasoisiinkin aiheisiin, kuten sisäilmaongelman vakavuuden puntarointiin, aineellisiin uhrauksiin tai kiistelyyn vakuutusyhtiöiden ja terveydenhuollon ammattilaisten kanssa. Yhteistä rationaalisen yksilön identiteetin rakentamiselle on, että vaikka kirjoittajat eivät tee eroa sairaan kategoriaan, he lieventävät sen leimaavuutta kuvaamalla itsensä johdonmukaisiksi, asiantunteviksi ja voimakkaiksi toimijoiksi, jotka selviytyvät vastoinkäymisten keskellä. Kahdessa seuraavassa otteessa (6 ja 7) kirjoittajat kuvaavat, kuinka suuria ponnistuksia, uhrauksia ja toiminnan kurinalaisuutta selviytyminen on edellyttänyt.

Ote 6: "Terveydentilani koheni vähitellen päästyäni pois vaurioituneista työtiloistani ja heitettyäni ohjeiden mukaan pois kaikki työtilassani olleet, homeiden saastuttamat tavarat, irtaimen paperin, lehtiöt, vihkot. Roskiin lensivät muun muassa kaikki kenttämuistiinpanoni eri puolille [maanosa] tekemiltäni tutkimusmatkoilta. Pienestä osasta oli onneksi kopiot toisaalla. Opiskelijoiden koevastaukset oli tietenkin käytävä läpi, jotta kaikki saivat arvosanansa. Huoneessani olleet kirjat yliopisto otti puhdistettavakseen.

Fyysisen kunnon palautuminen ennalleen oli suuri helpotus. Vasta myöhemmin alkoivat pikkuseikat harmittaa, kuten se, että kenttätyödokumentaationi oli hävinnyt, samoin kuin niihin liittyvät alustavat käsikirjoitukset ja muut konseptit. Tällä tavalla kosteusvaurio vaikutti myös työuraani. Ei tuntunut järkevältä jatkaa tutkimuksia aineistoista, joiden perustiedot olivat hävinneet. Onneksi kykenin suuntaamaan energiani muihin asioihin ja ennen kaikkea jatkamaan elämääni.” (Olli)

Kirjoittaja, joka kuvauksen ajankohtana työskenteli tutkijana, kuvaa vointinsa parantuneen vas- ta työtilan vaihdon ja saastuneiden materiaalien hävittämisen jälkeen. Hän korostaa monin tavoin tätä ratkaisua. Ensinnäkin hän käyttää ääriilmausta, kuinka hän hävitti kaikki työtilassaan olleet saastuneet materiaalit ja myös kaikki kenttämuistiinpanot. Lisäksi hän kuvaa kenttämuistiinpanojen olleen äärimmäisen tärkeitä - ne oli koottu eri puolille vierasta maanosaa tehdyillä tutkimusmatkoilla - ja lopulta välttämättömiä siten, että ilman niitä tutkimuksen jatkaminen ei ollut järkevää. Tiheä kuvaus, retoriikan sanastolla yksityiskohdilla ja kertomuksilla vakuuttaminen, luo autenttista ja totuudellista vaikutelmaa.

Kuvaamalla yksityiskohtaisesti menetyksen vakavuutta kirjoittaja rakentaa itselleen sellaisen rationaalisen, jopa ideaalisen yksilön identiteettiä, joka toimii tiukoissakin paikoissa johdonmukaisesti harkiten ja hallitun luovasti ("kykenin suuntaamaan energiani muibin asioibin") sekä itsekuria osoittaen ("ohjeiden mukaan"), jota uhrauksen suuruus vielä korostaa. Rationaalisuus ei kuitenkaan tarkoita oman edun tavoittelua, sillä kirjoittaja kertoo käyneensä "tietenkin" opiskelijoiden koevastaukset läpi, vaikka omaa terveyttään riskeeraten. Tässä mielessä kirjoittaja vierailee myös hyvän ihmisen identiteetissä.

Seuraavassakin otteessa ponnistelut ovat rankkoja, vaikka poikkeavat sisällöllisesti edellisestä otteesta.

Ote 7: "Olen karsinut elämästäni asioita, väitellyt puolisoni ja sukuni kanssa oireistani ja valinnoistani, välttelen tiettyjä rakennuksia, pidän hengityssuojainta kasvoillani, jos joudun pakollisesti olemaan homeisessa rakennuksessa, noudatan tiukkaa ruokavaliota ja hoidan yleensäkin itseäni em. asioilla. Nyt kuusi kuukautta altisteisesta tilasta poissaolleena minusta alkaa tuntua siltä, että paraneminen on alkanut." (Kristiina)

Otteessa kirjoittaja kuvaa kurinalaista elämäänsä, jonka johdosta paraneminen on ollut mahdollista (kuten välttänyt tiettyjä rakennuksia, käyttänyt hengityssuojainta,kohentanutruokavaliota).Näin ollen sekä otteen 6 että 7 kirjoittajat kuvaavat itsensä itseohjautuvina, vaikeina hetkinä päätöksentekoon ja itsekuriin kykenevinä henkilöinä siten, että näiden kuvausten sisällöt toimivat rationaalisen toimijan identiteetin määreinä. 
Joissain kirjoituksissa sinnikkyyteen ja itsekunnioitukseen nojaava rationaalisuus saattaa nousta keskeiseksi myös ilman edellisten otteiden tyyppistä kehitystarinaa. Seuraavan otteen kirjoittaja on eläkkeellä kärsittyään vuosia vaikeista oireista, jotka hän liittää työpaikkansa haitalliseksi todettuun sisäilmaan. Hän myös kuvaa kärsivänsä tämän seurauksena monista kemiallisista herkkyyksistä, jotka rajoittavat voimakkaasti hänen päivittäistä elämäänsä.

Ote 8: "Sairauteni on todellinen ja tilanteeni usein vaikea. Sairastelun jatkuminen vie voimavaroja aivan turhaan, mutta yritän olla vahva! [...] Uskon, että vahvoille ihmisille annetaan enemmän koettelemuksia. Vaikka elämäni on välillä haasteellista, yritän hyväksyä jotenkin tapahtuneet asiat ja katson luottavaisesti tulevaan aikaan.” (Laura)

Tässä otteessa rationaalisen toimijan identiteettiä edustaa erityisesti pyrkimys kohdata vaikeat ja todelliset ongelmat silmästä silmään, hyväksyen ne realistisesti. Vaikka otteessa on edellisiä vähemmän konkreettista kuvausta ponnistelujen ja uhrauksien laadusta, kirjoittaja osoittaa tässäkin autonomiaa, arvokkuutta ja määrätietoisuutta, joiden kautta rakentuu rationaalisen toimijan identiteetti.

\section{OIKEUTETTU UHRI}

Oikeutetun uhrin identiteetti rakentuu kuvauksista, joissa korostuu pyyteetön tuki ja toisilta ihmisiltä saatu ymmärrys. Tukea voi saada läheisiltä ihmisiltä, ammattilaisilta tai asiantuntijoilta, jotka samalla oikeuttavat sairaan kategorian. Poiketen aiemmin analysoiduista identiteeteistä, oikeutettu uhri ei siten pyri ottamaan etäisyyttä sairaan kategoriaan, vaan päinvastoin korostaa sitä. Esimerkkinä tästä toimii seuraava ote, joka on tässä tarkempaan analyysiin otettava katkelma otteen 1 riveiltä 2-6. Otteessa kirjoittaja kuvaa toisten ajatelleen aluksi, että vika ei olisi työtilassa vaan oirehtijassa itsessään.

Ote 9: "Koska olin oman yksikköni ensimmäinen sairastunut, niin ajatteli ensin myös työterveyslääkäri ja sairaus ehti puhjeta astmaksi ennen kuin sain väistömääräyksen ja nyt olen astmaatikko lopun elämääni.” (Marja)
Tässä kuvauksessa sairaan oikeutus rakennetaan terveysviranomaisen toimenpiteistä (tilan vaihtamisen määräys) ja arviosta (astmadiagnoosi). Näillä virallisilla oikeutuksilla palautetaan kirjoittajan itsekunnioitus ja arvo.

Kirjoittajan kokemus legitimoidaan kuvauksissa myös esimerkiksi seurustelukumppanilta tai ystäviltä saadun ymmärryksen avulla. Seuraavassa otteessa kirjoittaja, joka oli jäänyt eläkkeelle työperäisen astman takia, kuvaa sairautensa aikana kahdelta taholta saamaansa tukea.

Ote 10: "Lääkäri myös rohkaisi ja lohdutti. Hän sanoi, että yritä kestää, vaikka nämä työpaikkasairastumiset ovat kovin rankkoja ja tutkimukset erittäin pitkäkestoisia. [...] Vieläkin muistan kiitollisena mm. entisen työkaverini tapaamista kaupan hedelmätiskillä. Hän ei tiennyt tilanteestani, ja kysyi vain työpaikkani kuulumisia. Minulta pääsi itku, ja pikaiseen kerroin, missä tilanteessa olen. Hän oli kovin ymmärtäväinen.” (Hertta)

Ote alkaa kuvauksella siitä, miten tärkeää empaattista tukea kirjoittaja sai lääkäriltä tämän diagnosoidessa hänen oireensa ammattisairaudeksi. Saman tyyppisesti kirjoittaja kuvaa myös kohtaamansa entisen työtoverinsa ymmärtäväisyyttä. Otteen erityinen emotionaalisuus liittyy muualla tekstissä esille tulevaan kuvaukseen, jossa esimies kiistää sairauden ja kirjoittaja irtisanotaan.

Ulkoista hyväksyntää korostavissa kuvauksissa ei välttämättä aina mainita konkreettista tahoa tai henkilöä, kuten seuraavasta otteesta on nähtävissä.

Ote 11: "Vaikka kuulostaa hullulta, olen iloinen, että jos joku oire oli pakko olla, se oli juuri astma kuuluvine yskineen, koska sitä ei voi kukaan kiistää.” (Marja)

Vaikka kyseessä olisi vakavakin sairaus, toisilta saatu hyväksyntä legitimoimassa kärsimystä on niin tärkeää, että jopa yleisesti hyväksytty sairausdiagnoosi voi olla helpotus. Otteessa $10 \mathrm{kir}-$ joittaja korosta ääri-ilmauksella, että kukaan ei voi kiistää näin selkeää diagnoosia kuin "astma kuuluvine yskineen". Empatia ja erityisaseman oikeutuksen tunnustaminen ovat tarpeellisia eri- 
tyisesti siksi, että ne vapauttavat sisäilmaongelmista kärsivän luulosairausepäilyksestä. Varsinkin sellaisilta tahoilta saadut tunnustukset, joilla ei itsellään ole sisäilmaongelmia ja joilla on kirjoittajaa korkeampi status (kuten terveet työssäkäyvät ja asiantuntijat), ovat selkeitä oikeutetun uhrin identiteetin määrittäjiä.

\section{KÄRSIMYKSEN VIISASTAMA}

Kärsimyksen viisastaman identiteettiä rakentavat maininnat henkisestä kasvusta, moraalin kehittymisestä ja uusista tärkeistä ihmissuhteista, jotka liittyvät kärsimyskokemuksiin. Esimerkiksi aineistosta poimitut kaksi lyhyttä lausetta - "Olen löytänyt unden maailman, joka ei ole ollenkaan abdistava" ja "Ilman tätä vaikeaa sairautta en olisi saanut tutustua eri puolilta Suomea oleviin ihaniin ihmisiin" - kuvaavat tätä kärsimyksestä seurannutta iloa ja rauhaa. Kun aikaisemmissa identiteeteissä tärkeää oli sellaisten 'ulkoryhmäläisten' katse, joilla itsellään ei ole sisäilmaongelmia, tämän identiteetin kohdalla painottuu yhteisyys sisäilmaongelmista kärsivien ihmisten välillä.

Viisastuminen voi olla myös suhteellisuudentajun kasvua kuten seuraavassa (jo otteessa 1 nähdyssä) katkelmassa. Kirjoittaja kuvaa siinä keskustelua tulevasta, sisäilmaongelman takia tehtävästä työtilan vaihdoksesta.

Ote 12: "Välillä kyllä minua on kiehuttanut istua muuttoa koskevissa kokouksissa kuuntelemassa väninää muutaman homeisen kirjan takia. Itsekin arvostan kirjoja, ja niistä harmittaa luopua, mutta hengittäminen on vielä arvokkaampaa.” (Marja)

Otteessa kirjoittaja kuvaa tuntemuksiaan, kun työtoverit suhtautuivat epäluuloisesti saastuneiden kirjojen poistamiseen. Hän korostaa omaa kärsimyksen viisastamaa identiteettiään vertaamalla työtovereidensa materialistista asennetta ("väninää muutaman homeisen kirjan takia") ja omaa nykyistä ymmärrystään elämän arvojärjestyksestä ("hengittäminen on vielä arvokkaampaa"). Materialistista ja tätä henkisempää elämänasennetta verrataan myös seuraavassa otteessa. Kirjoittajan oireet ovat lieventyneet, ja hän on päässyt palaamaan työhönsä.

Ote 13: "Negatiivinen asia eli sairastuminen voi myös olla positiivinen asia, näin itse koen.
Olen saanut uusia ystäviä, jotka ovat kokeneet vielä kovempia kuin minä. Omat elämänarvot ovat muuttuneet täysin olen päässyt pois materiaalisesta kulutusjuhlasta, arvostan todellisia asioita ja ihmisiä ja ennen kaikkea nautin päivä kerrallaan elämästäni. Se on jo paljon koska vuosina [vuosiluvut poistettu] elin minuutin kerrallaan. En pelkää enään kuolemaa ja ennen kaikkea rakastan tätä elämääni, koska olen saanut jatkaa sitä läheisteni kanssa.” (Ronja)

Kirjoittaja kuvaa sairastumisensa monella tavalla positiiviseksi asiaksi. Hän kuvaa saaneensa uusia itseäkin kovempia kokeneita ystäviä, joka on auttanut elämänarvojen muuttamisessa materiaalisista seikoista todellisten asioiden ja ihmisten arvostamiseen. Lisäksi hän kuvaa päässeensä kuolemanpelosta elämän rakastamiseen. Hänen kuvauksensa materialismikritiikistä, todellisten asioiden ja ihmisten arvostamisesta ja elämänsä rakastamisesta toimivat määreinä kärsimyksen viisastamalle identiteetille.

\section{YHTEISTEN OIKEUKSIEN AJAJA}

Sisäilmasta sairastumista saatetaan kuvata myös kollektiivisena kokemuksena. Kohtalotovereita yhdistävät jaetut intressit, jotka ilmenivät sosiaalisen tuen, diagnoosien sekä rakennusten tutkimisen ja korjausten vaatimuksina. Edellä kuvatuista identiteeteistä poiketen Yhteisten oikeuksien ajajan identiteetissä käytetäänkin pronominia me. Sanalla viitataan muihin sisäilmasta sairastuneisiin ja sillä rakennetaan eroa muihin ryhmiin, kuten rakentamisen ammattilaisiin, lääkäreihin ja valvontaviranomaisiin, jotka saatetaan esittää hyvinkin negatiivisessa valossa. Tästä eronteosta huolimatta sairastuneiden sisäryhmä laajenee usein osaksi kattavampia kategorioita, kuten työtekijöitä tai ihmisiä. Seuraava ote havainnollistaa tätä kuvauksen monikerroksisuutta. Kirjoittaja on kertonut muualla, että hänen mahdollisuutensa työskennellä ovat vakavasti uhatut.

Ote 14: "Varsinainen työpisteeni sijaitsee [paikka] alakerrassa isossa työhuoneessa, jossa meitä on yhteensä 7 vakituista työntekijää. Meillä kaikilla on oireita, jotka voidaan laskea sisäilmaoireiluksi. Melkein kaikki ovat olleet yhteydessä oireistaan työterveyteemme (yksi on käynyt omalla lääkärillään asuinpaik- 
kakunnallaan). Kävin toukokuussa [vuosi] työterveyshoitajalla kertomassa [paikka] näkyvistä kosteusvaurioista, jotka olimme työkaverini kanssa huomanneet alakerran ison työhuoneen katossa.” (Liisa)

Kirjoittajan kuvaus sisältää monia kiinnostavia kohtia. Ensinnäkin hän kertoo, että kaikki vakituiset työntekijät kärsivät sisäilmaongelmista mainiten myös heidän lukumääränsä. Retorisen lähestymistavan sanastolla kuvattuna kirjoittaja lisää vakuuttavuutta soveltamalla ääri-ilmaisua kaikki ja kvantifiointia "yhteensä 7". Toiseksi hän jatkaa kuvaustaan yksityiskohtaisena narratiivina, jolla hän lisää uskottavuutta saman tyyppisesti kuin rationaalisen toimijan identiteetissä tehdään. Nyt kertoja ei kuitenkaan kuvaa omaa yksilöllistä tarinaansa, vaan kohtalotovereittensa yhteistä tarinaa, jossa "meillä kaikilla" on oireita, yhteinen huoli ja jaettuja pyrkimyksiä. Kirjoittaja ei myöskään tyydy kuvaamaan sisäryhmää vain kategoriaa sairas hyödyntämällä, vaan käyttää kattavampaa ja vähemmän leimaavaa kategoriaa työntekijät. Seuraava ote tarjoaa vielä moniulotteisemman esimerkin sisäryhmäkategorian laajentamisesta. Kirjoittaja on työttömänä ja pelkää, ettei voi työllistyä, koska on altistunut pahasti sisäilman epäpuhtauksille edellisessä työpaikassaan.

Ote 15: "Vaikka olenkin itse vain yksi potilastapaus, tiedän että meitä sairastuneita on jo tuhansia. Lähes kaikilla on samankaltainen tarina taustalla, vaikka sairastumispaikka ja oirekuva vaihteleekin tapauskohtaisesti hyvin paljon. Emme ole luulosairaita, vaan oikeasti vakavasti elimellisesti sairastavia ihmisiä, joilla ei ole tällä hetkellä juuri mitään ihmisarvoa tai turvaa. Yllättävän moni meistä on hyvin korkeasti koulutettuja, koska mm. niin monet koulut, korkeakoulut ja virastot kärsivät sisäilmaongelmista. Mikään taho ei ole edes yrittänyt tähän mennessä kartoittaa sairastuneiden määrää ja tilannetta.” (Rita)

Tämän otteen kuvauksessa on edellistä aineistootteita muistuttavia, mutta myös niitä täydentäviä piirteitä. Toisin kuin aikaisemmissa identiteeteissä, sairauden maininta ("Vaikka olenkin itse vain yksi potilastapaus") liitetään laajan sisäryhmän osaksi ("meitä sairastuneita on jo tuhansia") ja luulosairaus kiistetään kollektiivisena ilmiönä ("Emme ole luulosairaita"). Luulosairauden kiistämisen jälkeen, oma ryhmä määritellään kolmella kiinnostavalla täydennyksellä. Sisäryhmä määritellään (a) "oikeasti vakavasti elimellisesti" sairastaviksi, (b) osaksi yleiskategoriaa ihmiset ja (c) ryhmäksi, jolla on korkea koulutustaso. Näillä täydennyksillä sisäryhmä laajennetaan yhdestä potilastapauksesta luotettavaksi ryhmäksi, joka on osa samaa laajaa kategoriaa ihminen, johon myös ulkoryhmäksi mielletyt ryhmät kuuluvat. Samalla tehdään jo aikaisemmista identiteeteistä tuttua erontekoa luulosairauteen.

Edellä esitettyjen aineisto-otteiden perusteella Yhteisten oikeuksien ajajan identiteetti rakentuu siis monen tyyppisistä aineksista, joissa yhdistyy aikaisemmin esiteltyjen identiteettien ominaisuuksia kollektiivisella tasolla. Ensinnäkin tähän identiteettiin kuuluu huoli vakavasti sairastavista sisäryhmän jäsenistä. Toiseksi tämä sisäryhmä muodostaa väärinkohdellun intressiryhmän. Kolmanneksi tämä sisäryhmä kehystetään vielä laajemmalla neutraalilla ryhmäkategorialla, kuten työntekijät tai ihmiset. Näillä kuvaustavoilla kirjoittajat sekä suojaavat uhattuja identiteettejään että legitimoivat oikeuksiaan ja tuen tarvettaan.

\section{YHTEENVETO JA PÄÄTELMIÄ}

Tunnistimme yhteensä kuusi identiteettityyppiä, joita aineistomme kirjoittajat rakensivat samalla, kun he kuvasivat työpaikkansa sisäilmaongelmiin liittyviä kokemuksiaan. Nämä identiteetit olivat normaali yksilö, hyvä ihminen, rationaalinen toimija, oikeutettu uhri, kärsimyksen viisastama ja yhteisten oikeuksien ajaja. Taulukossa 1 esitämme kootusti, mikä on näiden identiteettien ydinviesti, miltä stigmaattisilta identiteeteiltä niillä puolustaudutaan ja millaista toimijuutta niiden kautta tarjoutuu.

Rakentuvien identiteettien kirjo heijastaa sisäilmasta sairastuneen aseman dilemmaattisuutta. Dilemmaattisuus näkyy muun muassa siinä, miten kirjoittajat joutuvat tasapainottelemaan oman tarinansa autenttisuuden ja stigmaattisten kategorioiden välillä. Stigmoja, joita tunnistamamme identiteetit asettuvat vastustamaan, ovat (luulo)sairaan, vastuuntunnottoman, kyvyttömän, poikkeavan ja itsekeskeisen valittajan identiteetit. Yksilötasolla kirjoittajan normaalius, kyvykkyys, kunnollisuus, viisaus ja rationaalisuus ovat niitä peitsiä, joilla identiteettikamppailu py- 
Taulukko 1. Tunnistetut identiteetit

\begin{tabular}{|l|l|l|l|}
\hline IDENTITEETTI & MITÄ KOROSTAA & $\begin{array}{l}\text { MITÄ STIGMAA } \\
\text { TORJUU }\end{array}$ & TOIMIJUUS \\
\hline 1. Normaali yksilö & $\begin{array}{l}\text { Argumentoi, että sairastuminen } \\
\text { ongelmarakennuksessa on normaali reaktio } \\
\text { epänormaaliin tilanteeseen }\end{array}$ & Sairas & $\begin{array}{l}\text { Heikko } \\
\text { Puolustuksellinen }\end{array}$ \\
\hline $\begin{array}{l}\text { 2. Hyvä ihminen } \\
\text { vainottaa humaaniuden, vastuullisuuden ja } \\
\text { vireyden eetosta }\end{array}$ & $\begin{array}{l}\text { Vastuuntunnoton } \\
\text { Itsekeskeinen }\end{array}$ & $\begin{array}{l}\text { Aktiivinen } \\
\text { Puolustuksellinen }\end{array}$ \\
\hline $\begin{array}{l}\text { 3. Rationaalinen } \\
\text { toimija }\end{array}$ & $\begin{array}{l}\text { Osoittaa valmiutta perusteltuun ja } \\
\text { sinnikkääseen toimintaan }\end{array}$ & $\begin{array}{l}\text { Kyvytön } \\
\text { Heikko }\end{array}$ & $\begin{array}{l}\text { Aktiivinen } \\
\text { Vahva yksilötasolla }\end{array}$ \\
\hline $\begin{array}{l}\text { 4. Oikeutettu uhri } \\
\text { todellinen tila }\end{array}$ & $\begin{array}{l}\text { Heikko } \\
\text { Riippuvainen muista }\end{array}$ \\
\hline $\begin{array}{l}\text { 5. Kärsimyksen } \\
\text { viisastama }\end{array}$ & $\begin{array}{l}\text { Korostaa kykyä nöyryyteen, kiitollisuuteen } \\
\text { ja viisauteen }\end{array}$ & $\begin{array}{l}\text { Heikko } \\
\text { Symbolinen }\end{array}$ \\
\hline $\begin{array}{l}\text { 6. Yhteisten } \\
\text { oikeuksien ajaja }\end{array}$ & $\begin{array}{l}\text { Argumentoi, että sisäilmasta sairastuminen } \\
\text { on kollektiivinen ilmiö. } \\
\text { Vaatii oikeuksia ja tukea sairastuneille } \\
\text { ihmisille. }\end{array}$ & $\begin{array}{l}\text { Luulosairas } \\
\text { Poikkeava }\end{array}$ & $\begin{array}{l}\text { Aktiivinen } \\
\text { Vahva ryhmätasolla }\end{array}$ \\
\hline
\end{tabular}

ritään voittamaan. Ryhmätasolla peitsiksi käyvät ryhmävoima ja ryhmän kyvykkyys.

Vaikka tämä kamppailu heijastaakin niitä vallitsevia yhteiskunnallista käytänteitä ja keskusteluita, joita sisäilmaongelmien ympärillä Suomessa käydään, saattaa samantyyppinen kamppailu liittyä sairastamiseen yleisemminkin. Yksilökeskeisessä ja yksilön vastuuta korostavassa kulttuurissa, sairastuminen itsessään on uhka yksilön positiivisille identiteettityölle ja moraaliselle arvolle (11, 21-23). Sisäilmasta sairastumisen kokeneen kohdalla uhka voi kuitenkin olla erityisen suuri sen osittaisen kiistanalaisuuden takia mutta myös siksi, että vaatiessaan tilojen tutkimista ja korjaamista, sairastunut asettuu avoimesti vastustamaan yksilön vastuuta korostavaa terveysdiskurssia, jonka mukaan yksilö on viimekädessä itse vastuussa terveydestään.

Samanaikaisesti, kun kirjoittajat rakentavat identiteettejä, joissa he korostavat yllä listattuja positiivisia attribuutteja, he rakentavat usein myös sairastuneen identiteettiä. Rationaalisen toimijan ja kärsimyksestä viisastuneen identiteeteissä sairaus linkittyy orgaanisesti edellä listattuihin positiivisiin määreisiin. Oikeutetun uhrin ja yhteisten oikeuksien ajajan identiteeteissä haetaan puolestaan erityisesti vahvistusta ja oikeutusta sairastuneen identiteetille. Vain normaalin yksilön identiteetissä kirjoittajat rakentavat aktiivisesti voimakasta rajaa kategorioiden sairas ja terve välille ja kieltäytyvät luokittelemasta itseään ensiksi mainittuun. Normaalin yksilön identiteetissä rakennettu ympäristö on kuitenkin käänteisesti tärkeä osa tätä identiteettiä. Laajas- ti ymmärrettynä identiteetti ei tässä tapauksessa sisällä vain ihmiskategoriaan liitettyjä määreitä tai toimintoja, vaan sen olennaisena osana on rakennettu ympäristö. Tästä seuraa se, että niin kauan kun normaalin yksilön identiteettiä rakennetaan, vaurioitunut rakennus on väistämätön osa ihmisen identiteettiä.

Identiteettityön monimutkaisuus ja paradoksit ilmenevät myös siinä, miten kirjoittajat käsittelevät kertomustensa ulkoryhmiä. Vaikka kirjoittajat viittaavatkin toisinaan työnantajiin, vakuutusvirkailijoihin tai lääkäreihin vähättelijöinä, vastuunpakoilijoina ja ongelman aiheuttajina, he eivät missään vaiheessa katkaise täysin nuoraa meidän ja muiden väliltä. Goffman onkin kuvannut, kuinka stigmatisoidut ihmiset pyrkivät mahdollisimman sujuvaan ja ristiriidattomaan vuorovaikutukseen ns. 'normaaleiden' ihmisten kanssa (11). Tämä sujuva vuorovaikutus on keskeistä heille, sillä stigmaan liittyy usein haitta tai vajavaisuus, jonka kanssa selviytyminen edellyttää apua ja tukea. Myös sisäilmasta sairastumisen kokenut voi olla hyvin riippuvainen muiden avusta ja siksi hänelle voi olla tärkeää tulla ymmärretyksi silläkin uhalla, että joutuu luopumaan mahdollisuudesta voimakkaisiin rajantekoihin.

Tunnistamamme identiteetit tarjoavat myös erilaisia toimijuuden muotoja. Toimijuudella tarkoitamme tässä kykyä toimia omatoimisesti annettujen ehtojen puitteissa. Identiteeteistä erityisesti rationaalinen toimija ja yhteisten oikeuksien ajaja korostavat aktiivista toimijuutta, joka sallii omien asioiden edistämisen ja puolustautumisen. 
Myös hyvä ihminen korostaa aktiivista toimijuutta mutta muodoltaan se on edellisiä normatiivisempi. Muissa identiteettityypeissä toimijuus näyttäytyy passiivisena ja edellisiä heikompana. Nämä erilaiset tarjotut toimijuudet heijastelevat sitä tasapainottelutyötä, jota kirjoittajat tekevät. Yhteisten oikeuksien ajaja haastaa lukijansa ottamaan kantaa, kun taas hyvä ihminen neutraloi tilanteen ja rakentaa samaistavaa siltaa lukijan ja oman tarinansa välillä. Tämä sillan rakentaminen näyttääkin olevan keskeinen osa kertomusten logiikkaa. Se ilmenee ainakin kahdessa asiassa. Ensinnäkin eri identiteettejä vuorotellaan kirjoituksissa siten, että ulkopuolinen lukija pystyy vielä samaistumaan kirjoittajaan, vaikka itse sisäilmaongelmaan liittyvä kokemusmaailma olisi hänelle vieras. Toiseksi kirjoittajat käyttävät toisinaan käsitettä ihminen esittäen siten itsensä ja lukijansa kuuluvaksi samaan yhteiseen kategoriaan. Yhteisen kategorian esittämisen kautta on mahdollista rakentaa jaettuja identiteettejä, jotka puolestaan voivat lisätä ihmisten halukkuutta empatiaan, tukemiseen ja auttamiseen (15). Kirjoittajat siis kutsuvat lukijaa ymmärtämään.

Tunnistamamme identiteetit ovat riippuvaisia rajallisesta aineistostamme. Todennäköisesti useimmat kirjoituskeräykseen osallistuneet ovat melko aktiivisia ja riittävän hyvässä tilanteessa olevia ihmisiä, kun taas kaikkein vaikeimmassa asemassa olevat eivät välttämättä ole jaksaneet tai pystyneet osallistumaan. Lisäksi aineistomme on pitkälti naisten kirjoittama. Kirjoittajat olivat myös tietoisia siitä, että heidän tekstinsä arkistoidaan. Tämä kaikki on voinut vaikuttaa siihen, miten tekstit on kirjoitettu.

Sisäilmaongelmien laadullinen ja yhteiskuntatieteellinen tutkimus on vasta aivan aluillaan, vaikka tiedon tarve on ilmeinen. Analyysimme antaa viitteitä siitä, että vastaajat, joiden työkykyyn sisäilmaongelma oli vaikuttanut kaikkein voimakkaimmin, käyttivät keskimäärin useampia eri identiteettityyppejä kuin ne, joilla vaikutus oli heikompi. Tämä viittaa siihen, että suojatakseen itsenään, uhkaavimmassa tilanteessa olevat saattavat joutua muita enemmän hankalaan tasapainotteluun tarjolla olevien kulttuuristen resurssien välillä. Tämän tarkempi todentaminen vaatii luonnollisesti jatkotutkimusta. Käytännön näkökulmasta olisi tärkeää tutkia sitä, miten henkilöt, jotka ovat kokeneet sisäilmasta sairastumisen, tasapainoilevat vaihtoeh- toisten identiteettien välillä myös arkisissa, kasvokkaisissa vuorovaikutustilanteissa esimerkiksi lääkärin vastaanotolla. Tästä ei ole vielä tutkimusta. Menetelmämme etu tällaisiin vuorovaikutustilanteisiin nähden on se, että sen avulla on mahdollista tavoittaa merkitysrakenteita, jotka eivät välttämättä avaudu tutkijalle kasvokkaisten vuorovaikutustilanteiden analyysin yhteydessä. Monenlaista tutkimusta siis tarvitaan. Kun selontekoja ei tulkita kirjaimellisena informaationa vaan kulttuuristen resurssien valikoivana käyttönä, ihmiselle poikkeustilanteissa ominainen moraalinen tasapainoilu saadaan analyysin piiriin.

Analyysillämme on myös sovellusarvoa käytäntöön. Aikaisempi tutkimus on osoittanut, että lääkärin ja potilaan vuorovaikutus koetaan kunnioittavana niissä tilanteissa, joissa potilas kokee tuleensa kohdelluksi yksilönä. Tämän lisäksi se on osoittanut, että potilaan kokemuksen ja sairausluokitteluiden kyseenalaistaminen koetaan nöyryyttävänä $(5,9,24,25)$. Analyysimme konkretisoi sitä, miten kirjoittajat tasapainoilevat diskursiivisessa miinakentässä, joka sisältää vaihtoehtoisia identiteettejä ja joukon uhkaavia stigmoja. Kunnioittava vuorovaikutus lääkäripotilas/asiantuntija-asiakas suhteessa edellyttää sitä, että auktoriteetti tunnistaa ja hyväksyy tavallista haastavamman identiteettien rakentamisen ja stigmojen karttamisen. Tämä voi tapahtua muun muassa empaattisen puheen kautta (26).

Yhteenvetona voidaan todeta, että kokemus sisäilmasta sairastumisesta voi johdattaa ihmisen tavallista haastavampaan identiteettityöhön, jonka päämääränä on, kuten kaikilla meillä muillakin, tunnustuksen saaminen sille, että oma toiminta on ymmärrettävää ja hyväksyttävää niistä lähtökohdista käsin, josta ihminen toimii.

Tämän artikkelin pohjana on käytetty samaa aihepiiriä hieman eri rajauksella käsittelevää englanninkielistä artikkelia: Finell E, Seppälä T, Suoninen E. "It was not me that was sick, it was the building": Rhetorical identity management strategies in the context of observed or suspected indoor air problems in workplaces. Qual Health Res 2018;28:1366-77.

doi: $10.1177 / 1049732317751687$

1 Alkuperäisen aineiston koko oli 62 kirjoitusta. Näistä kuusi kirjoitusta oli lähetetty kirjoittajien luvalla Hengitysliiton järjestämästä aineistonke- 
ruusta. Koska näissä kirjoituksissa oli erilainen retorinen konteksti kuin muissa kirjoituksissa, ne on jätetty tämän analyysin ulkopuolelle. Tämän artikkelin aineistoksi valittiin niiden 20 vastaajan kirjoitukset, jotka käsittelivät erityisesti työpaikan sisäilmaongelmia.

\section{RAHOITTAJAT:}

Hengityssairauksien tutkimussäätiö, Suomen Akatemia (nro. 323125)

\section{KIRJOITTAJIEN KONTRIBUUTIOT:}

Finell on saattanut tutkimuksen alkuun, suunnittelut sen, osallistunut aineiston keräämiseen, analysoinut aineiston ja tulkinnut sen, luonnostellut artikkelin ja kriittisesti tarkastanut sen.

Suoninen on analysoinut aineiston ja tulkinnut sen, luonnostellut artikkelin ja kriittisesti tarkastanut sen.

Seppälä analysoinut aineiston ja tulkinnut sen sekä kriittisesti tarkastanut käsikirjoituksen.

Finell, E., Suoninen, E., Seppälä, T. Discourse analysis of employees' identity work in the context of indoor air problems in the workplace. Sosiaalilääketieteellinen aikakauslehti - Journal of Social Medicine 2020:57: 359-37 I.

\section{Abstract}

The relationship between indoor air problems and health effects is somewhat contested. This may require intensive identity work from those who suffer from health problems associated with indoor air. Using discourse-oriented methods, we analysed the identities that respondents constructed in writing about their experiences of indoor air problems in the workplace. The data came from essays collected through the Finnish Literature Society ( $\mathrm{N}=20$ respondents). We identified six identities: the normal individual, the good person, the rational actor, the legitimate victim, the wise sufferer, and the promoter of in-group rights. These identities differed according to how the distinction between healthy and unhealthy people was drawn, whether individual characteristics or group membership were emphasised, the weakness or strength of the agency offered by the identity, and the stigmas the identities sought to counter. Individual respondents constructed several different identities, and the identity work involved striking a balance between them. The central aim of the identity work was to seek recognition as a moral person. Dealing respectfully with patients in the context of indoor air problems requires healthcare professionals to be aware of the challenging identity work that patients do, and to recognise the stigmas this identity work seeks to address.

Keywords: indoor environmental problems, identity, contested illnesses, discourse analysis

Saapunut 12.02.2020

Hyväksytty 11.06.2020

\section{LÄHTEET}

(1) Mendell MJ, Mirer AG, Cheung K, ym.

Respiratory and allergic health effects of dampness, mold, and dampness-related agents: a review of the epidemiologic evidence. Environ Health Perspect 2011;119:748-756. doi: 10.1289/ehp.1002410

(2) Fisk WJ, Eliseeva EA, Mendell MJ. Association of residential dampness and mold with respiratory tract infections and bronchitis: a meta-analysis. Environ Health 2010;9:72. doi: 10.1186/1476-069X-9-72

(3) Kanchongkittiphon W, Mendell MJ, Gaffin $\mathrm{JM}, \mathrm{ym}$. Indoor environmental exposures and exacerbation of asthma: an update to the 2000 review by the institute of medicine. Environ Health Perspect 2015;123:6-20. doi: 10.1289/ehp.1307922

(4) Magnavita N. Work-related symptoms in indoor environments: a puzzling problem for the occupational physician. Int Arch Occup Environ Health 2015;88:185-196. doi: 10.1007/s00420-014-0952-7

(5) Armentor JL. Living with a contested, stigmatized illness: experiences of managing relationships among women with fibromyalgia. Qual Health Res 2017;27:462-473. doi: $10.1177 / 1049732315620160$

(6) Finell E, Seppälä T. Indoor air problems and experiences of injustice in the workplace: a quantitative and a qualitative study. Indoor Air 2018;28:125-134. doi: 10.1111/ina.12409

(7) Dumit J. Illnesses you have to fight to get: facts as forces in uncertain, emergent illnesses. Soc Sci 
Med 2006;62:577-590.

doi: 10.1016/j.socscimed.2005.06.018

(8) Shriver TE, Bodenhamer A. The enduring legacy of black lung: environmental health and contested illness in Appalachia. Sociol Health Illn 2018;40:1361-1375.

doi: 10.1111/1467-9566.12777

(9) Dickson A, Knussen C, Flowers P. Stigma and the delegitimation experience: an interpretative phenomenological analysis of people living with chronic fatigue syndrome. Psychol Health 2007;22:851-867. doi: $10.1080 / 14768320600976224$

(10) Mengshoel AM, Sim J, Ahlsen B, ym. Diagnostic experience of patients with fibromyalgia - a meta-ethnography. Chronic Illn 2018;14:194211.

doi: $10.1177 / 1742395317718035$

(11) Goffman E. Stigma. Notes on the management of spoiled identity. Upper Saddle River, NJ: Prentice-Hall; 1963.

(12) Erikson EH. Identity and the life cycle. New York, NY: W.W.Norton \& Company; 1980.

(13) McAdams DP. The psychology of life stories. Rev Gen Psychol 2001;5:100-122. doi: 10.1037//1089-2680.5.2.100

(14) Tajfel H, Turner J. An integrative theory of intergroup conflict. Kirjassa: Austin W, Worchel S. (toim.) The social psychology of intergroup relations. Monterey, CA: Brooks Cole; 1979, 33-47.

(15) Haslam C, Jetten J, Cruwys T, ym. The new psychology of health: unlocking the social cure. London: Routledge; 2018.

(16) Suoninen E. Identiteettien rakentuminen. Kirjassa: Jokinen A, Juhila K, Suoninen E. (toim.) Kategoriat, kulttuuri ja moraali. Tampere: Vastapaino; 2012.

(17) Jokinen A, Juhila K, Suoninen E. Diskurssianalyysi - Teoriat, peruskäsitteet ja käyttö. Tampere: Vastapaino; 2016.

(18) Finell E, Nätti J. The combined effect of poor perceived indoor environmental quality and psychosocial stressors on long-term sickness absence in the workplace: a follow-up study. Int. J. Environ. Res. Public Health 2019;16:4997. doi: 10.3390/ijerph16244997

(19) Jokinen A, Juhila K, Suoninen E. Kategoriat, kulttuuri ja moraali. Tampere: Vastapaino; 2012.
(20) Billig M. Arguing and thinking. Cambridge: Cambridge University Press; 1987.

(21) Charmaz K. Stories of suffering: subjective tales and research narratives. Qual Health Res 1999;9:362-382. doi: $10.1177 / 104973239900900306$

(22) Whittle HJ, Palar K, Ranadive NA, ym. "The land of the sick and the land of the healthy": disability, bureaucracy, and stigma among people living with poverty and chronic illness in the United States. Soc Sci Med 2017;190:181-189. doi: 10.1016/j.socscimed.2017.08.031

(23) Ellis J, Boger E, Latter S, ym. Conceptualisation of the 'good' self-manager: a qualitative investigation of stakeholder views on the selfmanagement of long-term health conditions. Soc Sci Med 2017;176:25-33. doi: 10.1016/j.socscimed.2017.01.018

(24) Lian OS, Hansen AH. Factors facilitating patient satisfaction among women with medically unexplained long-term fatigue: a relational perspective. Health 2016;20:308-326. doi: $10.1177 / 1363459315583158$

(25) Lian OS, Robson C. Socially constructed and structurally conditioned conflicts in territories of medical uncertainty. Soc Theory Health 2019;17:23-39. doi: $10.1057 / \mathrm{s} 41285-018-00082-w$

(26) Diette GB, Rand C. The contributing role of health-care communication to health disparities for minority patients with asthma. Chest 2007;132:802S-809S.

doi: 10.1378/chest.07-1909

\section{EERIKA FINELL}

VTT, akatemiatutkija

Tampereen yliopisto

Yhteiskuntatieteiden tiedekunta

Eero SuONINEN

YTT, yliopistonlehtori

Tampereen yliopisto

Yhteiskuntatieteiden tiedekunta

TuIJA SEPpäLÄ

VTT, tutkijatohtori

Tampereen yliopisto

Yhteiskuntatieteiden tiedekunta 